IRSH 56 (20I I), Special Issue, pp. I07-I 24 doi:I0.I0I7/S00208590 I I000484 (C) 20I I Internationaal Instituut voor Sociale Geschiedenis

\title{
The Just Wage in Early Modern Italy: A Reflection on Zacchia's De Salario seu Operariorum Mercede
}

\author{
A N D REACARA C A USI \\ Department of History, University of Padua \\ E-mail: andrea.caracausi@unipd.it
}

SummarY: This article aims to understand norms and values pertaining to the definition of just wages in early modern Italy. The starting point is the treatise by the jurist Lanfranco Zacchia, De Salario sen Operariorum Mercede, which appeared in the mid-seventeenth century and represented the first attempt to collate a set of rules on wages based on the traditions of Roman and canon law. After a brief presentation of the treatise, I shall analyse the meanings and concepts of wages, and then consider the elements that determined the just wage. To understand how prescriptions were seen by individuals, I shall also compare them with information about court cases and rulings compiled by Zacchia in another book, the Centuria decisionum ad materiam Tractatus de Salario, and with the rest of the existing literature. Evidence from my comparison will allow us to understand the interaction and reciprocal influences between juridical thought and daily work practice, and underline the fact that wages were based on a complex system of norms and values where individuals, their social positions, skills, and experience determined the recognition of the just wage with reference to the local context.

\section{WAGES AND THEIR HISTORY}

During the early modern age, wages were at the basis of labour relations, especially in commodified labour. A wide range of workers leased their work to public or private employers, receiving payment in the form of money or goods. An analysis of how wages (i.e. the payment for a particular job) came to be considered "just" at certain times and places seems necessary in order to understand the complex system of norms and values regulating work. Furthermore, the debate is more relevant during periods of economic change, as in the Italian context of the sixteenth and seventeenth centuries when the spread of new forms of production caused a need for the rules concerning labour relations to be redefined.

In recent decades, scholars of the social and economic history of preindustrial Europe have investigated more deeply the history of wages, 
previously considered a field of labour or price history. ${ }^{\mathrm{I}}$ During medieval and early modern times wages depended on many factors, including time, skill, and industriousness, and their amounts were difficult to standardize. ${ }^{2}$

On the other hand, the role of justice with respect to wages is poorly understood, which is regrettable considering the importance of law to early modern labour relations. ${ }^{3}$ In general, the focus is on such formal aspects as guild regulations, local statutes, and theological texts. ${ }^{4}$ Studies have shown important features, such as high levels of negotiation, but conflicts between groups or organizations have been analysed more frequently, while micro-conflicts between actors have not been investigated. Regarding the debate on the "just wage", more attention has been paid to

I. Henry Phelps Brown and Sheila V. Hopkins, A Perspective of Wages and Prices (London [etc.], I98 1); Ruggiero Romano (ed.), I prezzi in Europa dal XIII secolo ad oggi (Turin, 1966). 2. James Farr, Artisans in Europe, I300-19I4 (Cambridge, 2000), pp. I5 I-I 52; Simon A.C. Penn and Christopher Dyer, "Wages and Earnings in Late Medieval England: Evidence from the Enforcement of the Labour Laws", The Economic History Review, 43 (1990), pp. 356-376; Donald Woodward, "The Determination of Wage Rates in the Early Modern North of England", The Economic History Review, 47 (1994), pp. 22-43; Jeremy Boulton, "Wage Labour in Seventeenth-Century London", The Economic History Review, 49 (I996), pp. 268-290; Francesca Trivellato, "Salaires et justice dans les corporations vénitiennes au i 7 e siècle. Le cas des manufactures de verre", Annales HSS, 54 (1999), pp. 245-273; Luca Mocarelli, "Wages and the Labour Market in the Building Trade in I 8th Century Milan", Jabrbuch für Wirtschafts Geschichte, 2 (2004), pp. 6I-8I; Guido Guerzoni, "Assetti organizzativi, tecniche gestionali e impatto occupazionale delle fabbriche ducali estensi nel Cinquecento", in Simonetta Cavaciocchi (ed.), L'edilizia prima della rivoluzione industriale (Florence, 2005), pp. 771-802.

3. Michael Sonenscher, Work and Wages: Natural Law, Politics and the Eighteenth-Century French Trades (Cambridge, 1989).

4. Raymond De Roover, "The Concept of the Just Price: Theory and Economic Policy", The Journal of Economic History, I 8 ( 1958 ), p. 424; Armando Sapori, "Il giusto prezzo nella dottrina di S. Tommaso e nella pratica del suo tempo", in idem, Studi di storia economica medievale (Florence, 1940), pp. 189-227. Different approaches can be found in Penn and Dyer, "Wages and Earnings in Late Medieval England", pp. 356-376; Woodward, "The Determination of Wage Rates", pp. 22-43; Francesca Trivellato, Fondamenta dei vetrai. Lavoro, tecnologia e mercato a Venezia tra Sei e Settecento (Rome, 2000); idem, "Salaires et justice dans les corporations vénitiennes"; Renata Ago, Economia barocca. Mercato e istituzioni nella Roma del Seicento (Rome, 1998).

5. Carlo Poni, "Misura contro misura: come il filo da seta divenne sottile e rotondo", Quaderni storici, 47 (198I), pp. 385-423; idem, "Norms and Disputes: The Shoemakers' Guild in Eighteenth-Century Bologna", Past E Present, I23 (1989), pp. 80-108; Michael Sonenscher, "Journeymen, the Courts and the French Trades I78 I-I79I", Past E Present, I I4 (1987), pp. 77-109; Catharina Lis, Jan Lucassen, and Hugo Soly (eds), "Before the Unions: Wage Earners and Collective Action in Europe, I300-1 850 ", Supplement to the International Review of Social History, 39 (1994); Simona Cerutti and Carlo Poni (eds), Conflitti nel mondo del lavoro [Quaderni storici, 27] (1992), pp. 38 I-508; Walter Panciera, "Padova, I704: L'Antica Unione de' Poveri Lanieri contro la ricca Università dell'Arte della Lana”, Quaderni storici, 29 (1994), pp. 629-653; Alberto Guenzi, Paola Massa, and Fausto Piola Caselli (eds), Guilds, Markets and Work Regulations in Italy, I6th-19th Centuries (Aldershot, I998), Part II, "Profession, Monopoly and Conflict", pp. 2 I I-395. 
the medieval period thanks to the prominence of scholastic thought. ${ }^{6}$ Authorities such as Thomas Aquinas, Baldo degli Ubaldi, and Bartolo da Sassoferrato are fundamental for the early modern period.

However, between the sixteenth and seventeenth centuries the Italian peninsula experienced many economic transformations in trade and manufacture, including the rise of merchant-manufacturers, which had important consequences for labour relations and wage payments. As rural and urban proto-industry spread, there was a reconversion to luxury production and the growth of wage labour in and around guilds. ${ }^{7}$ Furthermore, the development of more organized regional states caused public administration to expand, leading to the rise of a new class of salaried workers. Those transformations probably stimulated the new publications on just wages that began to appear in the mid-seventeenth century. ${ }^{8}$

This article aims to understand how it was possible to determine a just wage in an early modern, segmented society; at the same time, I shall show how juridical thought was relevant to daily practice in workshops. My starting point is the treatise by the Roman jurist Lanfranco Zacchia, De Salario sen Operariorum Mercede [Wages or Workers' Wages], ${ }^{9}$ which represents the first collection of rules and prescriptions entirely concerning wages. It was first published in Italy in $1658 .^{10}$

After a brief introduction to Zacchia's book, the first section of this article analyses the various concepts and terminology used to define wages. This variety does not imply a specific ranking of labour nor of wage relations, but it is necessary to determine what a just wage was.

6. For the early modern period see Gino Barbieri, "Il giusto salario negli scrittori italiani del Cinque e Seicento", Annali della Facoltà di Economia e Commercio dell'Università di Bari, 9 (1949), pp. 238-328 [republished as "La remunerazione del lavoro negli scrittori italiani della Controriforma", in idem, L'ordine economico nei pensatori ecclesiastici dell'epoca moderna (Bari, I96I)]; Trivellato, "Salaires et justice dans les corporations vénitiennes"; idem, Fondamenta dei vetrai, pp. 5I-8I; Ago, Economia barocca, pp. 102-107, I33-I57, 201-202; James Shaw, The Justice of Venice: Authorities and Liberties in the Urban Economy, I550-1700 (Oxford, 2006), pp. I 47-148.

7. Paolo Malanima, La fine del primato. Crisi e riconversione nell'Italia del Seicento (Milan, I998).

8. Gino Barbieri has argued that those new publications on wages reflected changes in economic mentality (especially the emergence of individualism). See Barbieri, "La remunerazione del lavoro", pp. 8I-83.

9. Lanfranci Zacchiae, I.V.D. ET ADVOCATI ROMANI, De Salario sen Operariorum Mercede. Tractatus in tres partes distinctus, in quo questiones omnes, tàm ad Theoricam, quàm ad Praxim pertinentes proponuntur, pertractantur, resoluuntur, Opus Iurisperitis omnibus tàm in Foris, quam in Scolis versantibus utile, \& necessarium, Cum Duplici Indice. Romaes Ex Typographia Nicolai Tinassi, M.DC.LVIII, Superiorum Permissu \& Privilegio.

Io. Barbieri, "La remunerazione del lavoro", pp. 93, 97. Francesca Trivellato noted that Gino Barbieri was the first scholar to underline the importance of Zacchia's book for the concept of wages during the early modern period; Trivellato, "Salaires et justice dans les corporations vénitiennes", p. 264, n. 42. 
During the second part I will show how Zacchia presents the just wage. The Roman jurist stresses the importance of contractual agreements signed by individuals, and his idea is that "just wages" were first and foremost individually determined. Beyond that, Zacchia underlines the role of law, custom, and, finally, judges. I shall show when and how judges were involved in setting the just wage, normally in the absence of the previous elements. In the last part of this article, I shall highlight some key points concerning the complex system of norms and values that governed the idea of wages in early modern Italy.

In order to understand how the prescriptions offered in Zacchia's book influenced or were taken into consideration by society as a whole, I shall integrate this analysis with rulings from the Sacra Rota Romana also collected by Zacchia in his Centuria decisionum ad materiam Tractatus de Salario [One Hundred Judgments on Wages], ${ }^{\mathrm{II}}$ and the extant literature on wage-related court cases. ${ }^{\text {I2 }}$ The aim is not to give more relevance to the culture of the elites than to that of the "lower" classes, nor to underline differences between them. My aim is to understand the reciprocal influences between juridical thought and daily work practice, their interactions, and the consequences for the early modern economy and society. That approach could also allow us to identify some key points in early modern labour relations and work ethics, which will be useful for comparison with other countries and cultures.

\section{DE SALARIO SEU OPERARIORUM MERCEDE: AN OVERVIEW}

In the mid-seventeenth century (I658 and I659), two books appeared written by the Roman jurist Lanfranco Zacchia: the De Salario seu Operariorum Mercede and the Centuria decisionum ad materiam Tractatus de Salario. Information on Lanfranco Zacchia's own life is scanty, ${ }^{\mathrm{I} 3}$ but his De Salario sen Operariorum Mercede is a very substantial work (covering over 400 pages) and the book had great resonance in the legislation of the seventeenth and eighteenth centuries. Thanks to the many cases discussed, De Salario represents a very rich source for understanding early modern labour relations

I I. Centuria decisionum ad materiam tractatus de salario et operariorum mercede, d. Lanfranci Zacchiae, Iureconsulti Romani Pertinentium, Venetiis, Apud Turrinum, I664. Superiorum permissu et privilegium.

I 2. Barbieri, "La remunerazione del lavoro"; Trivellato, "Salaires et justice dans les corporations vénitiennes"; Ago, Economia barocca, pp. 18 I-182, 201-202; Shaw, The Justice of Venice, pp. I47-I 49; Mocarelli, "Wages and the Labour Market"; Andrea Caracausi, Dentro la bottega. Culture del lavoro in una città d'età moderna (Venice, 2008), pp. 45-146; idem, "I giusti salari nelle manifatture della lana di Padova e Firenze (s. XVI-XVII)", Quaderni storici, 45 (2010), pp. $857-884$.

I3. Lanfranco Zacchia was probably the son or nephew of the famous doctor Paolo Zacchia (I 584-1659); Trivellato, "Salaires et justice dans les corporations vénitiennes", p. 264. 
and it allows us to reconstruct the doctrine of salary during the two centuries after the Counter-Reformation. ${ }^{14}$

Zacchia's De Salario consists of three parts and iro Quaestiones, i.e. questions on several aspects of wages, and it is impossible to summarize. The first part (Quaestiones I-XLIX) is a general introduction which analyses several issues relating to the nature of wages and labour relations. The second part (Quaestiones $\mathrm{L}-\mathrm{XC}$ ) deals instead with wages and their relation to each wage earner. The final part (Quaestiones XCI-CX) concerns the role of justice with respect to wages.

In the first part, Zacchia investigates the nature of wages: the terminologies and modalities of remuneration, the convenient (i.e. proper) wage, and the ways in which they could be increased or decreased. Starting from those general issues, Zacchia analyses a number of elements of wage relations, such as timing and forms of payment (from money to goods), and the lawfulness of working during holidays. He also considers rights and duties within wage relations.

Zacchia focuses on the importance of observing contractual agreements. In particular, he reminds us that wages must be paid regularly to workers who were brought in for a certain time in a specific place to do a job, and he is careful to discuss exclusive agreements between employers and employees. ${ }^{\text {Is }}$ $\mathrm{He}$ addresses several aspects of the rights and obligations arising from labour contracts, such as indemnity for infirmity, the rights and duties of fathers and employers concerning working children, the transmission of wages within the family, and the taxation of wages. ${ }^{16}$ Finally, a number of questions are discussed with respect to the ecclesiastical world.

Regarding early modern wage relations, Zacchia underlines the wide range of salaried workers, forms of remuneration, and methods of payments. The second part of his De Salario focuses on individual aspects of wage relations, according to the individual professions involved. Quoting them in alphabetical order, he shows the wide diversity of "employees" or "salaried workers": ambassadors and bankers, craftsmen and doctors, but also prostitutes, famuli and familiars (domestic servants). Everyone has a specific place and character in Zacchia's picture, reflecting the diversity of wage relations and their internal logic, rights, and duties. The aim was probably to present a universal picture of an ideal society in terms of the different groups of wage typologies that he sought to analyse. ${ }^{17}$

The last part of De Salario examines the role of justice with respect to wages. Zacchia examines judicial proceedings, focusing on courts that were competent to pass judgments on wages, looking also at the days on

I4. Barbieri, "La remunerazione del lavoro", p. 97, n. 40.

is. Zacchia, De Salario, Quaestiones XXII-XXIII.

I6. Ibid., Quaestiones V-VII, XLII-XLV.

17. Ibid., Quaestiones L-XC. 


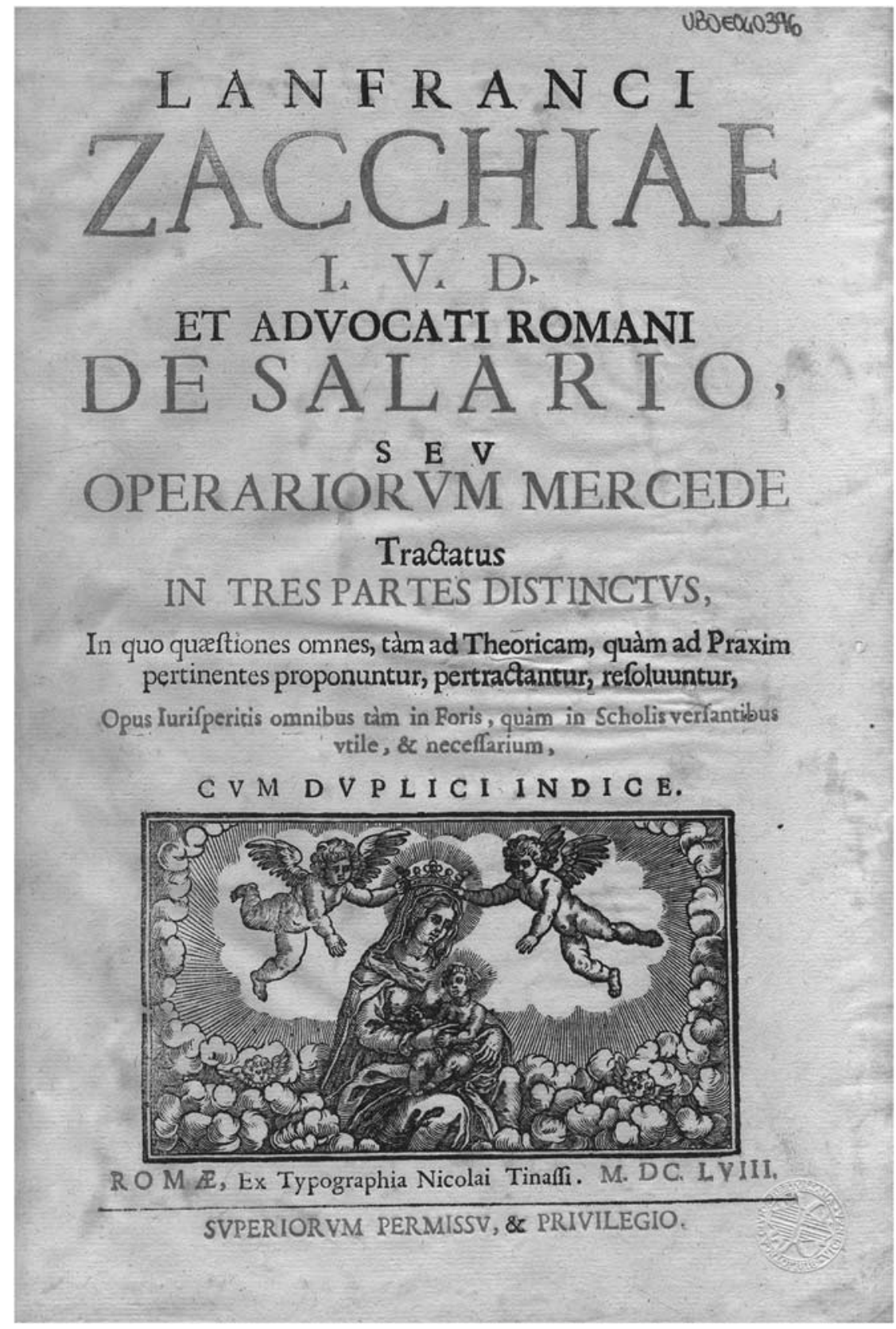

Figure I. Lanfranci Zacchiae, De Salario seu Operariorum Mercede, Romae, Ex Typographia Nicolai Tinassi, M.DC.LVIII.

Biblioteca civica Bertoliana di Vicenza. Used with permission. 
which it was possible for cases to be heard, and considering the legal remedies that might be implemented to ensure justice. Nor did Zacchia fail to examine the role of lawyers and witnesses and, finally, the types and hierarchy of proof.

The great jurist also introduced to his exposition specific issues concerning contracts, the election of capitoli, witnesses, compensation, claims, and debts. ${ }^{18}$ For his purpose, Zacchia preferred a more technical approach, focused on the legal system and juridical aspects. Praxis on wage conflict and judgments are at the core of the Centuria decisionum ad materiam Tractatus de Salario, which appeared in I659. Making extensive use of examples of judgments made in the Papal Courts of the Sacra Rota, Zacchia shows the praxis on wage justice, analysing the setting of a just wage, the repayment of damages, the role of judges, witnesses, and experts (periti), and the importance of aequitas, ${ }^{19}$ estimates and valuations (aestimationes), customs, and contracts.

\section{MEANINGS OF WAGE}

Zacchia opened De Salario with a simple but paradigmatic question: "What are wages?". Because he acknowledged "wage" to have many meanings, he was unable to offer a unique and monolithic definition. Quoting Benvenuto Stracca (the Anconite author of the treatise De mercatura, sen mercatore, published in the mid-sixteenth century), ${ }^{20}$ Zacchia concluded that wage (salario) is an "ambiguous concept" (aequivoca vox), whose meaning depends both on solum (pension given based on the area of land) and "salt" (a commodity ultimately necessary for every human action). That last concept refers in particular to workers (operari) and everyone else who received a wage or any remuneration for work. Beyond those differences, Zacchia defined "wage" as "the remuneration due to recompense work". ${ }^{21}$

Wages are different not only in their meaning, but also in their genre. Zacchia identified four categories. First are the wages due for the effort of science and intellect, applying to judges, doctors, lawyers, assessors, and others. While the second category refers to familiari and domestic

I 8. Capitoli were the arguments submitted by the two parties involved in a case. They had to be proved by witnesses.

19. Aequitas could be translated as "fairness", while the medieval and early modern concept was quite different from that of the present. On the existence of different forms of justice and tribunal, especially distributive justice, see Giovanni Levi, “Aequitas vs fairness. Reciprocità ed equità fra età moderna ed età contemporanea”, Rivista di storia economica, 19 (2003), pp. $195-203$.

20. Benvenuti Straccae, Tractatus de mercatura seu mercatore [...] Primae particulae ultimae partis principalis. Quomodo procedendum sit in causis mercatorum, Lugduni, apud Sebastianum de Honoratis, I5 58.

21. "Salarium est remuneratio debita pro operis retributione"; Zacchia, De Salario, pp. 5-6. 
servants of the "prince", the third includes wages gained "jointly" for science and intellect and physical labour, such as for captains and soldiers. Zacchia recognized such a division in the classification of waged workers of the scholastic tradition. At that point, however, Zacchia identified a fourth category of wage, one surprisingly not quoted earlier, which included the wages of those engaged only in physical labour in "mercenary occupations". ${ }^{22}$

On the one hand, the Roman jurist argued that the meaning of wages was indeterminate. On the other, he drew clear distinctions between the four categories of wages. The division depended not on labour relations nor on the form of remuneration, but on the faculties that allowed an individual to earn a wage (science and intellect versus physical work) and the function of the individual within society (such as the household servants of the "prince" or soldiers in the defence of the state). In his ranking of a wage's category, Zacchia recognized the ideal of early modern society which gave greater dignity to intellectual than to physical work. However, the inclusion of a fourth type of wage, previously absent from scholastic thought, implies that Zacchia recognized the specific position and growing importance of wage labour from the late fifteenth to the seventeenth centuries. ${ }^{23}$

That different use of the term "wage" seems to be present in the second part of the treatise too. There, Zacchia used the term "wage" (salario) with respect to thirty-one out of forty professions. Exceptions were craftsmen, bankers, coadiutori, divinatori, inventors, witnesses, huntsmen (associated with the term mercede), and soldiers (with the term stipendium). ${ }^{24}$

However, the distinctions employed were not entirely clear. Zacchia was certainly not making positive or negative judgements about the status of workers without any well-defined professional rank. Throughout the treatise, the terms and meanings used change frequently, and it is surprising that such apparent vagueness in the use of the term "wage" was similarly present in the language of ordinary people, including not only judges, but merchants and workers too. The words used to indicate remuneration for work were very different. During court cases, people might refer without making any distinction to "salary and wages" or "salary or wages", previously using the term "price": the "price of his wage" or the "price usually paid for wages". Moreover, the term most frequently used is another: "money" (denaro), followed by the particular skill concerned or the more general term "work".

22. "Cose mercenarie". See ibid., p. 7. On this point see also Trivellato, "Salaires et justice dans les corporations vénitiennes", p. 264. "Mercenaries" were people whose labour was for hire, rather than soldiers; Shaw, The Justice of Venice, p. 148.

23. Barbieri, "La remunerazione del lavoro", pp. II4-I I 5. The first three were the categories stated in the classification of waged workers compiled by Baldo degli Ubaldi; Trivellato, "Salaires et justice dans les corporations vénitiennes", p. 264, n. 43.

24. Zacchia, De Salario, Quaestiones L-XC. The coadiutores assisted or deputized for others in public office. The divinatores practiced divination. 
We read of "money in advance for work", "money for work", "money because of work", and "money for the time when he worked". ${ }^{25}$

Such variety was a consequence of a specific economic system that included a wide range of labour relations and forms of remuneration. Zacchia knew that, of course. During the sixteenth and seventeenth centuries, within much of Italian manufacturing, the widening division of labour and the emergence of merchant-entrepreneurs fostered a wide range of labour relations, including direct payment, subcontracting, nonprofessional relationships, and family ties, which sometimes coexisted in more than one workplace. Labour relations were very complex and included freely contracted waged work but also forced labour (as in hospitals), apprenticeships, and subcontracting.

Regarding wages, the main element was their timing. Zacchia stressed that point too. For the Roman jurist it was impossible to say "when the wage has to be paid", for that depended on the quality of work and people. It was necessary to know the "quality of people" ${ }^{26}$ If an operarius (someone who made his labour available in return for wages) was unable to work before receiving his wages, he was to be paid in advance. Zacchia gave us the example of tailors and other workers (who were all operari) who could not finish their work unless they received payment in advance, thereby justifying the practice. He knew that sometimes wages included not only payment for the work itself but also other "charges" and "costs", which recognized the realities of sub-contracting in the organization of production. ${ }^{27}$ That prescription was also well known by workers, as in the I 570 s, for example, when the textile weavers of Padua asked for an increase in their wages because of an overall rise in prices. They also wanted to receive "wages in advance, as was usual and customary", in order to support their families and pay their workers. ${ }^{28}$ As in the case of the textile weavers, Zacchia introduces us to an aspect of the subject that recurs frequently throughout his book: the need to link wages with the needs of individuals.

\section{OBSERVING THE CONTRACTS}

Given the wide range of labour relations, and especially the varieties and needs of the people involved, how is it possible to define a just wage?

25. Caracausi, Dentro la bottega, pp. 62-64; Germano Maifreda, L'economia e la scienza. Il rinnovamento della cultura economica fra Cinque e Seicento (Rome, 20Io), pp. I45-I48. See also Archivio di Stato, Florence [hereafter, ASF], Arte della lana [hereafter, AL], Register 285, fo. I06v; Archivio di Stato, Padua [hereafter, ASP], Università dell'arte della lana [hereafter, UL], Register 70, fo. 2 I9v. For eighteenth-century France see Sonenscher, Work and Wages, ch. 6.

26. Zacchia, De salario, Quaestio XIIII, ch. I.

27. Ibid.

28. ASP, UL, Register 79, fo. 43 Ir-v. 
Zacchia answers that point in his Quaestio IX, which was concerned with the competens wage, meaning the "convenient", "legitimate", or "just" wage. ${ }^{29}$ How can that amount be determined? For Zacchia, the first determinant was the "law of the prince". That prescription, however, was immediately limited. The jurist recognized that an agreement between parties had an inescapable value and was to be observed absolutely. ${ }^{3 \circ} \mathrm{In}$ fact, Zacchia says, the convenient wages are the wages "agreed between the parties". Agreement must be observed both by those who have promised wages and those who have accepted them. Following that prescription, wages had to be paid following a contract: the tenant, who had leased his work, could not ask for more, and the employer, who had rented the work of others, could not pay less. ${ }^{3 \mathrm{I}}$

The importance of agreements is confirmed by legal judgments. Courts rarely changed the wages stated in contracts. They preferred to legitimate the agreements. The judgments of the Sacra Rota Romana noted that contracts should not be terminated, and in the civil court of Murano (Venice), which had responsibility for cases involving glass workers, judges rarely changed original agreements. ${ }^{32}$ On is October I 544 , in a dispute on the payment of wages which was heard in the wool guild courts of Padua, a dyer demanded that a merchant pay him the wages agreed for his having dyed some clothes. The judge said that he should be paid "according to their exchange", without reference to wage levels. If individuals had agreed upon wages, those wages had to be paid "according to their agreement". 33 The juridical prescription ascribes an important role to the original promise, which was not to be violated. Wages had to be paid "according to their contract" for the time agreed "without any difference". In fact "it was not lawful to go against the promise", and workers should be paid "in accordance with the contract". ${ }^{34}$

The aim of such legal judgments was to encourage people to respect their contracts. Failing to pay wages according to what had been agreed was bad for the reputation of merchants and masters. They would be called "poor merchants", of "bad quality", and "vagabonds". 35 Those elements - Zacchia also tells us ${ }^{36}$ - would constitute a breach of contract. A child was not obliged to work for his master if the man was a "vagabond".

29. Zacchia, De Salario, Quaestio IX, p. 34 .

30. Ibid.

31. Ibid., chs I7-18.

32. Trivellato, "Salaires et justice dans les corporations vénitiennes", p. 266.

33. Caracausi, "I giusti salari”, p. 870 .

34. Ibid.

35. Caracausi, Dentro la bottega, p. 242.

36. Zacchia, De Salario, Quaestio XXIII, ch. I7. 
However, "because of his agreement" a father was obliged to put his sons into the workshop of his masters, despite its "poverty and disease". ${ }^{37}$

Contracts were also important as evidence for judges when they had to evaluate "just wages" (iuxtam summam). A confession by either of the parties was the highest proof, exceeding anything else. Confession was widely accepted in legal proceedings, having an important role because of its implied legal liability before God. ${ }^{3}$ In the absence of such confession, however, evidence could be submitted in the form of public and private instruments. Convenient wages were those stated in "written texts", such as merchant books, legal records, but private, informal agreements too (the chirografi). ${ }^{39}$ The use of that type of evidence meant that just wages were decided primarily by interested parties.

\section{LAW AND CUSTOM}

Further to the importance of contracts, there remains a question: What about the law?. For Zacchia, the just wage could not exceed "the right" (il giusto) and the amount stated by law. If wages exceeded the limits outlined by tax law (taxam legis), then they should not be paid. ${ }^{\circ}$ However, Zacchia was somewhat ambiguous on the point, recognizing that a judge had the power to set a just wage. ${ }^{4 \mathrm{I}}$ On the other hand, judges in court cases also frequently evaluated as just such wages as had been agreed by the parties, without reference to civic or guild statutes. ${ }^{42}$ Higher wages could also appear in other forms, such as gifts (donativi) or premiums (premi) if the employers judged the finished work to be worth more than the amount fixed by law.

In the early seventeenth century, Padua's wool merchant-manufacturers imposed a salary cap on master weavers. However, those amounts could be exceeded depending on the quality of work (merito) and the ability of the worker. In fact, once the merchant had received the clothes from the weaver, if he acknowledged that the master weaver deserved a higher

37. See Caracausi, Dentro la bottega, pp. I I4-1 22 on these types of conflict.

38. Giovanni Battista De Luca, Il dottor volgare. Libro ottavo. Del credito e del debito. Del creditore e del debitore; e del concorso de' creditori e dell'altre cose sopra questa materia di dare, ed avere (Venice, 1740 [Ist edn I640]).

39. Maura Fortunati, Scrittura e prova. I libri di commercio nel diritto medievale e moderno (Rome, I996); Simona Cerutti, Giustizia sommaria. Pratiche ed ideali di giustizia in una società di Ancien Régime (Torino, sec. XVII) (Turin, 2003), pp. 49-68; Andrea Caracausi, "Procedure di giustizia in età moderna. I tribunali corporativi", Studi storici, 49 (2008), pp. 323-360.

40. Zacchia, De Salario, Quaestio IX, ch. 21, p. 35 .

4I. Ibid., Quaestio II, p. I4, chs 5I-52.

42. Caracausi, Dentro la bottega, pp. I I4-I 22. 
wage he could give him a donation, if he saw fit. ${ }^{43}$ Merchants and judges recognized that personal agreements were more important than the laws of the prince. Moreover, just wages depended first and foremost on individual workers and their skills: an idea often posited by Zacchia.

Returning to the constitution of a convenient wage, after the laws of the prince and agreements, Zacchia introduced a third element: "custom", meaning wage that to "a certain extent is established by custom". ${ }^{44}$ "Customary" wages were "just". ${ }^{45}$ Custom included two aspects: the role of witnesses (testes deponents) and the locality of wages. The fact of "just wages following customs" could not be proved "beyond the place where the work had been provided". Customary wages reflected the local context, including civic and guild statutes. ${ }^{46}$

"Witnesses" meant people known locally. According to Zacchia, and other jurists for that matter too such as Giovanni Battista De Luca, ${ }^{47}$ witnesses were to be "worthy and honest" and at least two in number. The consequences are obvious: only a "citizen", well-known locally, could bring a larger number of witnesses to court. ${ }^{48}$ Some examples may be helpful here.

On 20 August I62I, in the wool guild court of Padua, during an action between a merchant and a beater, judges asked witnesses to assess the "present common use usually paid" for beating wool. Custom was proved by several witnesses, heard in court after a week, who stated that at the time they used to "solve and receive six pence for any quantity of waste wool". ${ }^{49}$ On I July I644, in the Sacra Rota Romana the merchants de Peculis asked to be allowed to pay a just wage of only ioo scudi per year to their giovine (assistant) Giuseppe Camerata from Bergamo. That amount represented the "customary" wage at Teramo where they lived. Giuseppe's witnesses had argued for higher wages, since those sums were "customary" for other cities such as Rome, Ancona, Pesaro, and Foligno. ${ }^{50}$ The communis aestimatio changed depending on local market trends, but it depended on the ability to produce a large number of witnesses in court in order to prove local customs. ${ }^{\text {I }}$ Sometimes it was also necessary to link local customs to the private agreement. Giovanni Maria Meggiorino proved through witnesses that "usually wages to the workers

43. Idem, "I giusti salari". On the role of gifts (donativi) in Murano glass manufacture, see Trivellato, "Salaires et justice dans les corporations vénitiennes", pp. $254^{-255}$.

44. Zacchia, De salario, Quaestio IX, pp. 35-36, chs 29-33.

45. Centuria decisionum, n. 4 , dec. I8.

46. Ibid., n. 2, dec. I4.

47. De Luca, Il dottor volgare, p. 345 .

48. On the role of witnesses, see Cerutti, Giustizia sommaria.

49. Caracausi, "I giusti salari".

50. Centuria decisionum, dec. I3, p. 28.

$5 \mathrm{I}$. On the role of the communis aestimatio (common estimation) in the local community in seventeenth-century Rome, see Ago, Economia barocca, p. I94. 
were one lira and four soldi for Ioo libbra of wool", but he had to prove also that the merchant Domenico Morello had promised that sum to him and other workers. ${ }^{22}$

\section{THE CONSTRUCTION OF THE JUST WAGE}

In the absence of laws, private agreements, and custom, how can just wages be assessed? How might damages be rewarded? Only at that point did Zacchia - following Giacomo Menochio - introduce the subject of the judge's discretion. ${ }^{53}$ In canon and Roman law, the role of the judge in defining just wages was marginal compared with the force of contractual agreement and local custom. Though marginal, that role sometimes required them to set a just wage. How could they establish that "just amount"? Judges had to consider many factors, such as the "quality of the person" (especially whether he was educated or uneducated), along with the quality of work and the time it took, as well as such factors as industriousness, skill, and expertise (industria, abilità e perizia). ${ }^{54}$ Leonardo Ravena had worked with the Genoese merchant Adamo Centurione, but he had no specific agreement concerning wages. The Genoese court of Sacra Rota stated that Ravena's salary was to be based first and foremost on the customs of the place, and then according to the quality of his person, industriousness, and expertise. ${ }^{55}$

What were the consequences of such prescriptions? First, just wages had to be higher or lower depending on the amount of work. Wages could not be the same for those who worked less and for those who put in a great deal more effort and care. ${ }^{56}$ If a public officer had to administer more than one city, then compared with earlier agreements wages must increase proportionately. 57 Workers understood too that their "work" merited its "reward", following the dictates of natural and civil law. On 23 May 1623, in the Venetian court of Giustizia vecchia [“Old Justice”] the apprentice caulker Pasqualino argued that "it is right that everyone's work brings its reward and that nobody is cheated of his just wage". ${ }^{8}$

52. Caracausi, "I giusti salari". Lira and soldi were units of account; libbra was the unit of measurement for weight.

53. Zacchia, De Salario, Quaestio IX, p. 37, ch. 39. See also Iacobi Menochii, De arbitrariis iudicum quaestionibus et causis (Lugduni, I606). This prescription continued to be observed even at the end of the eighteenth century. On Venetian law, see Marco Ferro, Dizionario del diritto comune e veneto (Venice, I778-178I), X; and Trivellato, "Salaires et justice dans les corporations vénitiennes", p. 264, n. 42.

54. Zacchia, De Salario, Quaestio IX, p. 37, ch. 44.

55. Quoted by Barbieri, "La remunerazione del lavoro", p. 99, n. 42.

56. Zacchia, De Salario, Quaestio IX, p. 37, chs 45-49.

57. Barbieri, "La remunerazione del lavoro", p. ıо०.

58. Cited by Shaw, The Justice of Venice, p. I47, n. 59. 
On 6 June 1625 the blacksmith Andrea Mazzon emphasized his "great sweat and labour", insisting on his "due wage, which cannot be denied him by divine and human law".59

Wages had also to follow economic trends, especially during famines, linking wages and subsistence. ${ }^{60}$ Workers referred to those ideals too. In I 577 the weavers of Padua asked for an increase in wages, claiming:

It is known to everyone how hard it is to live today, and also to dress, so that all the artisans of this city and also the workers (in the face of these calamitous times) are needy, so if they want themselves and their families to survive, their wages and goods and labour must be increased [...]. Therefore, having experienced that we cannot support ourselves and our families with the poor income and little reward in doing clothes, since it is so little that we can $[\ldots]$ resist and we need to leave the art of weaving and rely on other exercises $[\ldots]{ }^{6 \mathrm{r}}$

On the one hand wages depended also on objective criteria such as time, work, and economic trends. However, referring to the quality of the people and their abilities, Zacchia recognized a subjective meaning of wages, based on the individual skills and the social position of a worker (the qualitas personae). Zacchia recalls the long tradition of canon law, such as that indicated by scholastic thought: paying a just wage - and the just recompense of damage - was an action of both commutative justice (equality between payment and service) and distributive justice, depending on individual status. As for Thomas Aquinas, wages were "quasi quoddam pretium" [like a price], where it was impossible to provide a remedy if the damage exceeded half the cost and the estimate made by workers "does not have a uniform value but depends more or less on the expertise, industry, and skills of the same workers" ${ }^{62}$

The prescriptions invited judges, experts, and witnesses to evaluate the skills and expertise (abilità and perizia) of individual workers. On 30 May I608, the judges of the Sacra Rota Romana set an amount greater than the ordinary for the work of Dominus Quinones, based on its "quality, industriousness, and skill”. That wage (I00 scudi) was not excessive, but "highly convenient". ${ }^{63}$

59. Ibid., p. 147, n. 58.

60. Zacchia, De Salario, Quaestio IX, p. 38, ch. 48. Here Zacchia quotes Menochio, a jurist of the late sixteenth century: Iacobi Menochii, De arbitrariis, cas. 5I4. num. I I.

61. ASP, UL, Register 79, folio 43 Ir-v.

62. Zacchia, De Salario, Quaestio XCVIII, chs I-6. See also Sapori, Il giusto prezzo, pp. 198-204; Giacomo Todeschini, “'Ecclesia' e mercato nei linguaggi dottrinali di Tommaso d'Aquino", Quaderni storici, I05 (2000), pp. 585-622; De Roover, "The Concept of the Just Price", p. 424; Trivellato, "Salaires et justice dans les corporations vénitiennes", pp. 265-266. 63. Zacchia, Centuria decisionum, p. 24, dec. IX (also quoted by Trivellato, "Salaires et justice dans les corporations vénitiennes", p. 265, n. 45). 
Assessments were based both on professional experience within the community and on the knowledge of people. ${ }^{64}$ In the Florentine wool court at the end of the sixteenth century, to assess the level of damage to a master arising from the absence of his apprentice, the master weaver Biagio, son of Nicola, said he did not know if the apprentice Gerolamo "was able to stay as journeyman" because "he had not had him as journeyman in his workshop".6s Instead Prospero, son of Bartolomeo, said that the boy was not "able to stay as journeyman" because he "had had him in his house for three to four days and [...] he would not agree with him". Another witness said that Gerolamo "could stay as every other apprentice", and that "he deserved four scudi every year". Weavers evaluated the skills, merits, and expertise of Gerolamo, basing their opinions on their knowledge of him. To assess how the young knitter Taddea could "be merited for her wages", Camilla, the wife of Piero, said that she could earn twenty pence every week. She arrived at that amount because of her knowledge of Taddea and her work, because "when she lived in her house she could do the stockings with a needle". That wage "was deserved by every well-learned person". People who "want to pay convenient [...] pay these wages". ${ }^{66}$

Masters and merchants, journeymen, and apprentices quoted the ideals as stated in Zacchia's De Salario (merit and skills, industriousness, and expertise). It is not surprising that the word "work" (an objective concept $)^{67}$ was strictly related to "industriousness", "ability", or "skills" (subjective). On 2 I July i 565 Tommaso, son of Bernardo Alberigi from Florence, said that he was "for one year as apprentice with the wool merchant Niccolò, son of Matteo Cavalcanti", and that he "has done that work as a good minister". He attempted many times to ensure his "wage was convenient to his work and industriousness". ${ }^{68}$

Judgements of skill could be based on general considerations, such as the time spent with a master, but they also depended on individual workers. Wages were very difficult to standardize within general categories, and it was always necessary to know the apprentices or workers individually, as well as their qualities, such as their age, skills, and expertise.

64. On the experts charged with recording the current price in a specific place see Ago, Economia barocca, pp. 196-197.

65. Caracausi, "I giusti salari", p. 870.

66. Ibid., p. 872 .

67. "Work" (for which the same workers used the Italian term fatica) referred generally to the number of days, months, or years during which a worker had been employed, related to his efforts. However, the quantity of work in terms of time spent and occupation was not always easily assessed, especially in the case of piecework. During a case to determine the just wage of an apprentice, witnesses said that they could not precisely estimate the amount of work because "sometimes we work so much, sometimes less". See Caracausi, "I giusti salari".

68. ASF, AL, Register 37I, fo. 221 . 


\section{LOCAL KNOWLEDGE AND THE STATUS OF CONTRACT: TOWARDS AN EARLY MODERN ETHIC OF WAGES}

Combining legal doctrine and court cases allows us to identify some important points about the concept of wages, and just wages in particular, in early modern Italy. Zacchia offers a priori no prescriptions nor evaluations of wages. Beyond differences in their genre, the jurist was careful to show the variety of salaried workers, the absence of wage standards, and the complex world of rights and duties within labour relations. Regarding just wages, judges had to take great care. Abstract evaluations seem to have been very difficult, given the importance of individual knowledge, local practice, and contractual agreements.

Opening his work, Zacchia says that wages "are the aim of every human action" and that "each job deserves one price". ${ }^{69}$ He thereby dignifies wages and the human activity devoted to earning them. In evaluating wages, law and custom were important, but contractual agreements were more significant and judgments depended on them above all. It was possible to dispute levels of damages or rights and obligations, but it was impossible to change the idea of legally binding wages agreed on by contract. Only without proof concerning agreements, or in the event of damage, could judges assess wages.

Because of the specific, necessarily incomplete, contractual context, Zacchia considers in detail the rights and obligations of employers and employees. Workers hired for a certain time for a given wage would have to receive payment, even if they had not done the work. If the patron did not respect the wage agreement, workers could go to court to seek the entire amount as compensation. ${ }^{70}$ Furthermore, merchants and masters had to pay their workers at the right time,${ }^{7 \mathrm{I}}$ to avoid damaging their own reputations. ${ }^{72}$

Everyone knew well the prescriptions. On 2I November I565, a number of weavers from Cremona who had gone to Florence with a fiveyear agreement to work asked for settlement of their agreement. They also said that they had gone "far away from their houses" and were not "able to maintain their families". The weavers asked the court to oblige the merchants to observe their contracts, in fact "to give for five years [...] every year eight ducats for their provision to come to Florence for

69. Zacchia, De Salario, Quaestio I, ch. 2. On claims for rewarding work see Shaw, The Justice of Venice, p. I47; Caracausi, Dentro la bottega, pp. 76-78.

70. Zacchia, De Salario, Quaestio XXII, p. 77, chs 4, 8, I0-I I. On the importance of contracts, mainly for the obligations they impose on labourers, see also Robert J. Steinfeld, The Invention of Free Labor (Chapel Hill, NC [etc.], I99I).

7I. Barbieri, "La remunerazione del lavoro", p. 96, n. 37 (who cites also the prescription of St Carlo Borromeo, one of the major figures of the Counter-Reformation), p. I00, n. 50.

72. Caracausi, Dentro la bottega, pp. IOI-I I4, 242-244. 
work $[\ldots]$ to provide houses for five years where they would be able to work with their families and workers without paying other provisions" ${ }^{73}$

Respect for contracts was fundamental, and wages effectively placed individuals in a dialogue about the rights and obligations contained in the contract. ${ }^{74}$ The consequence was strict interdependence between workers and employers. Zacchia assigns a key role to contracts, allowing a limiting of differences resulting from social status. In disputes about wages, children too could take their cases to court, and this did indeed occur. ${ }^{75}$

Contracts were required for just wages. In his book Zacchia offers some material on good contracts and for assessing wages in cases of damage or in the absence of proof of agreement. The remuneration of work was surely a value depending on objective criteria, such as time taken, the work itself, and economic trends. But Zacchia also tells us that judges had to evaluate the quality of people, their social condition, skills, and expertise. He applies a strong subjective meaning to the concept of the just wage. Even the status of the proof meant that just wages were difficult for judges to evaluate in the abstract, and had to be linked to individuals (to their industriousness, skills, and expertise) because it was necessary to know the workers, their ages, and their professional skill. ${ }^{76}$ That point was common to many early modern Italian and European cities and explains how wages differed with respect to the duration, quantity, and quality of work. ${ }^{77}$

The idea of an individual concept of wages was well known among employers and employees. The Florentine Damiano, son of Antonio, asked only to earn a salary "competent and convenient to his person and to this exercise" of apprenticeship. Without a written contract, Damiano said only that he was sixteen years old and had been an apprentice for five years. On the other hand, the master weaver Bartolomeo, son of Francesco from Pontassieve, said that when the young girl Bartolomea stayed with him in his workshop "for her work [...] not only does she learn and deserve the cost of food and clothing but she also deserves a convenient salary and wage".$^{8}$

Convenient wages depended on both individual merits and pains. The local voice proved that. Witnesses and experts estimated damages or wages because they were both knowledgeable about skills and knew a

73. ASF, AL, Register 37I, case no. 106. On this type of judgment see also Trivellato, "Salaires et justice dans les corporations vénitiennes", pp. 268-269.

74. As argued especially by Sonenscher, Work and Wages, p. 192.

75. Zacchia, De Salario; Caracausi, Dentro la bottega, ch. 2.

76. Caracausi, "I giusti salari”.

77. Trivellato, "Salaires et justice dans les corporations vénitiennes", pp. 245-273; Mocarelli, "Wages and the Labour Market", pp. 6I-8I; Penn and Dyer, "Wages and Earnings in Late Medieval England”, pp. 356-376; Woodward, “The Determination of Wage Rates”, pp. 22-43; Boulton, "Wage Labour", pp. 268-290.

78. ASF, AL, Register 372, case no. 272: Bartolomeo claimed "fatica et opera sua". 
worker and his work. Quoting Zacchia, their assessment was based not "outside the place where work was done", but within the community. ${ }^{79}$ Following that prescription, wages were not simply a "price for the work" but a quasi quoddam pretium, linked to the community, the worker's personal quality, and local customs, as enshrined in an enduring medieval tradition.

An ideology of wages was based on a complex range of norms and values which put at their centre the individual action of actors, their social position, their skills, and their abilities. All those elements were strictly related to the local context (the community, the town, or the country), where customs were consolidated and practices legitimated, and where the ties between individuals and local environment determined - as the young fuller apprentice Giovanni from Padua claimed - the full recognition of their "just wages". ${ }^{8}$

79. See also ASF, AL, Register 372, case no. 352. The Florentine master weaver Francesco, son of Jacopo from Ascoli, said he could estimate the wage of an apprentice because "I have been a master weaver for thirty years; I have had apprentices and have judged on wages many times". 80. ASP, UL, Register 77 , fo. $527 \mathrm{v}$. 